Research Paper

\title{
Carbonic Anhydrase XII as an Independent Prognostic Factor in Advanced Esophageal Squamous Cell Carcinoma
}

\author{
Fumiaki Ochi ${ }^{*}{ }_{1}$, Atsushi Shiozaki ${ }^{*}{ }^{\bowtie}$, Daisuke Ichikawa ${ }^{1}$, Hitoshi Fujiwara ${ }^{1}$, Shingo Nakashima ${ }^{1}$, Kenichi \\ Takemoto ${ }^{1}$, Toshiyuki Kosuga ${ }^{1}$, Hirotaka Konishi ${ }^{1}$, Shuhei Komatsu ${ }^{1}$, Kazuma Okamoto ${ }^{1}$, Mitsuo \\ Kishimoto ${ }^{2}$, Yoshinori Marunaka ${ }^{3,4}$, Eigo Otsuji ${ }^{1}$ \\ 1. Division of Digestive Surgery, Department of Surgery, Kyoto Prefectural University of Medicine, Kyoto, 602-8566, Japan \\ 2. Department of Pathology, Kyoto Prefectural University of Medicine, Kyoto, 602-8566, Japan \\ 3. Departments of Molecular Cell Physiology and Bio-Ionomics, Graduate School of Medical Science, Kyoto Prefectural University of \\ Medicine, Kyoto, 602-8566, Japan \\ 4. Japan Institute for Food Education and Health, St. Agnes' University, Kyoto, 602-8013, Japan \\ * These authors contributed equally to this work.
}

$\bowtie$ Corresponding author: Dr. Atsushi Shiozaki, Assistant Professor, Division of Digestive Surgery, Department of Surgery, Kyoto Prefectural University of Medicine, 465 Kajii-cho, Kamigyo-ku, Kyoto 602-8566, Japan. Tel: +81 752515527, Fax: +81 752515522, e-mail: shiozaki@koto.kpu-m.ac.jp

(C) 2015 Ivyspring International Publisher. Reproduction is permitted for personal, noncommercial use, provided that the article is in whole, unmodified, and properly cited. See http://ivyspring.com/terms for terms and conditions.

Received: 2014.12.08; Accepted: 2015.06.19; Published: 2015.07.29

\begin{abstract}
Background: Although recent studies described important roles for carbonic anhydrase (CA) XII in epithelial carcinogenesis and tumor behavior, a consensus has not yet been reached regarding its clinicopathological significance in esophageal squamous cell carcinoma (ESCC). In the present study, we investigated its prognostic significance in ESCC. Materials and Methods: An immunohistochemical analysis was performed on 70 primary tumor samples obtained from ESCC patients who underwent esophagectomy, and the relationships between the expression of CA XII and various clinicopathological features or prognosis were analyzed. Results: Immunohistochemical staining showed that CA XII was primarily found in the cell membranes of carcinoma cells. Although the expression of CA XII was related to the PT category, it had no prognostic impact. We then examined the expression of CA XII according to the pT category. In PT2-3 ESCC, the 3-year survival rate of patients with the high grade expression of CA XII (29.1\%) was significantly lower than that of patients with the low grade expression of CA XII (70.3\%). Furthermore, a multivariate analysis demonstrated that the expression of CA XII was one of the most important independent prognostic factors following radical esophagectomy in PT2-3 ESCC. Conclusion: These results suggest that the expression of CA XII may be a valuable prognostic factor for patients with advanced ESCC. The results of the present study provide an insight into the role of CA XII as a biomarker in ESCC.
\end{abstract}

Key words: CA XII, Esophageal squamous cell carcinoma, Prognostic factor

\section{Introduction}

Hypoxia and acidosis are common phenomena in tumors, and adaptations to these micro environments are crucial for tumor growth and invasiveness (1). Hypoxia-inducible gene products have recently been investigated as candidates for biomarkers and therapeutic targets $(2,3)$. Carbonic anhydrase (CA) XII is a transmembrane zinc metalloenzyme that catalyzes the reversible hydration of carbon dioxide to 
form bicarbonate, and is involved in acidification of the microenvironment. Several recent studies reported the expression of CA XII in various types of cancers and its important roles in cancer development, tumor invasion, and possibly metastasis (4-11). However, a consensus has not yet been reached about its prognostic significance in cancer. Previous studies demonstrated that the expression of CA XII correlated with a good prognosis $(5,7,8)$, whereas others found that it correlated with a poor prognosis (9-11). Furthermore, the clinicopathological meaning and prognostic impact of the expression of CA XII has not yet been evaluated in esophageal cancer.

The objectives of the present study were to investigate the clinicopathological significance of the expression of CA XII and determine its relationship with the prognosis of patients with esophageal squamous cell carcinoma (ESCC). Our results revealed the prognostic significance of the expression of CA XII in advanced ESCC.

\section{Materials and Methods}

\section{Patients and primary tissue samples}

ESCC tumor samples were obtained from 70 patients with histologically proven primary ESCC who underwent esophagectomy (potentially curative R0 resection) at Kyoto Prefectural University of Medicine (Kyoto, Japan) between 1998 and 2009, and were analyzed retrospectively. These samples were embedded in paraffin $24 \mathrm{~h}$ after being fixed in formalin. The criteria for patient eligibility included the absence of synchronous tumors or multiple metachronous tumors and not having received preoperative chemotherapy or radiation therapy. We excluded patients with non-curatively resected tumors or non-consecutive data. All patients gave their written informed consent for inclusion in this study. Relevant clinicopathological and survival data were obtained from the hospital database. Staging was principally based on the seventh TNM staging system (12).

\section{Immunohistochemistry}

Paraffin sections (3- $\mu$ m thick) of tumor tissue were subjected to immunohistochemical staining for CA XII using the avidin-biotin-peroxidase method. Briefly, paraffin sections were dewaxed in xylene and hydrated through a graded series of alcohols. Antigen retrieval was performed by heating the samples in Dako REAL Target Retrieval Solution (Glostrup, Denmark) for $40 \mathrm{~min}$ at $95^{\circ} \mathrm{C}$. Endogenous peroxidase activity was quenched by incubating the sections for $30 \mathrm{~min}$ in $0.3 \% \mathrm{H}_{2} \mathrm{O}_{2}$. Sections were incubated for one hour at room temperature with the CA XII antibody (sc-374314; Santa Cruz Biotechnology, Santa Cruz, CA, USA) or hypoxia inducible factor (HIF)-1a antibody
(ESEE122; Novus Biologicals, Littleton, CO, USA). The avidin-biotin-peroxidase complex system (Vectastain ABC Elite kit; Vector Laboratories, Burlingame, CA, USA) was used for color development with diaminobenzidine tetrahydrochloride. Sections were counterstained with hematoxylin. These sections were then dehydrated through a graded series of alcohols, cleared in xylene, and mounted. Control sections of known positive ESCC were included in each antibody run, and negative control sections were produced by omitting the primary antibody.

Immunohistochemical samples stained with CA XII were graded semi-quantitatively by considering both the staining intensity and percentage of positive tumor cells using an immunoreactive score (IRS) (13). Staining intensity was scored as 0 (no staining), 1 (weak staining), 2 (moderate staining), or 3 (strong staining). The proportion of positive tumor cells was scored from 0 to 1.0. The score of each sample was calculated as the maximum multiplied product of the intensity and proportion scores (0 to 3.0).

\section{Statistical analysis}

Statistical analyses were carried out using Fisher's exact test to investigate the relationships between clinicopathological parameters and CA XII expression. Survival curves were constructed using the Kaplan-Meier method, and differences in survival were examined using the log-rank test. A multivariate analysis of the factors influencing survival was performed using the Cox proportional hazard model. Differences were considered significant when the associated $p$-value was less than 0.05 . All analyses were performed using statistical software (JMP, version 10; SAS Institute Inc., Cary, NC, USA).

\section{Results}

\section{CA XII protein expression in human ESCCs}

An immunohistochemical investigation with the CA XII antibody revealed the expression of CA XII in the parabasal cell layer of normal esophageal mucosa (Fig. 1A). We examined the expression of CA XII in 70 primary tumor samples of human ESCC based on their immunohistochemical reactivities. The CA XII protein was mostly expressed in the cell membranes of carcinoma cells (Fig. 1B). The CA XII score varied widely between the tumors. The minimum CA XII score was 0 , while the maximum was 2.5 (median= 0.40 ; mean \pm standard deviation $(\mathrm{SD})=0.65 \pm 0.64)$. Regarding the expression of CA XII in tumors, we divided ESCC patients into 2 groups by referring to the median and mean staining scores; a low grade CA XII expression group with staining scores $<0.5, n=35$, and a high grade CA XII expression group with staining scores $\geq 0.5, n=35$. Figure $1 C D$ shows the representa- 
tive histopathological findings of low or high CA XII expression samples. Relationships between the expression of CA XII and various clinicopathological parameters were analyzed (Table I). A correlation was observed between the expression of CA XII and the pT category (Table I). We then analyzed CA XII expression according to the $\mathrm{pT}$ category. In patients with pT1 ESCC $(n=33)$, the minimum CA XII score was 0 , while the maximum was 2.5 (median $=0.70$; mean $\pm S D=0.80 \pm 0.66$ ), and correlations were found between the expression of CA XII and venous invasion (Table II). On the other hand, the minimum CA XII score in patients with pT2-3 ESCC $(n=37)$ was 0 , while the maximum was 2.4 (median $=0.20$; mean $\pm S D=0.51 \pm 0.60)$, and no correlation was found between the expression of CA XII and any other clinicopathological parameter (Table III). Interestingly, the expression of CA XII was found in precancerous tissue such as severe dysplasia (Fig. 2A). These results suggested that CA XII may be induced in esophageal epithelial cells in the early stage of carcinogenesis.

We analyzed the localization of CA XII expression in tumors. In 25 cases, the expression of CA XII was found in the invasive front of the tumor. A correlation was found between the expression of CA XII in the invasive front and the CA XII score (Table I). Furthermore, CA XII and HIF-1a protein expression showed a similar pattern, suggesting its primary function contributing to $\mathrm{pH}$ homeostasis in microenvironment with hypoxia or acidosis (Fig. 2B).
Table I. Relationships between the expression of CA XII and clinicopathological features of esophageal cancer.

\begin{tabular}{|c|c|c|c|c|}
\hline \multirow[t]{3}{*}{ Variable } & & \multicolumn{2}{|l|}{ CA XII } & \multirow[t]{3}{*}{$\begin{array}{l}p \text {-Val } \\
\text { ue }\end{array}$} \\
\hline & & Low & High & \\
\hline & & $\begin{array}{l}\text { Score }<0.5 \\
(\mathrm{n}=35)\end{array}$ & $\begin{array}{l}\text { Score } \geq 0.5 \\
(\mathrm{n}=35)\end{array}$ & \\
\hline \multirow[t]{2}{*}{ Age } & $<65$ years & 20 & 20 & 1.000 \\
\hline & $\geq 65$ years & 15 & 15 & \\
\hline \multirow[t]{2}{*}{ Gender } & Male & 30 & 29 & 1.000 \\
\hline & Female & 5 & 6 & \\
\hline \multirow{2}{*}{$\begin{array}{l}\text { Location of the pri- } \\
\text { mary tumor }\end{array}$} & Ut-Mt & 24 & 23 & 1.000 \\
\hline & Lt-Ae & 11 & 12 & \\
\hline \multirow[t]{2}{*}{ Histological type } & $\begin{array}{l}\text { Well/moderately } \\
\text { differentiated SCC }\end{array}$ & 22 & 26 & 0.440 \\
\hline & $\begin{array}{l}\text { Poorly differentiated } \\
\text { SCC }\end{array}$ & 13 & 9 & \\
\hline \multirow[t]{2}{*}{ Tumor size } & $<50 \mathrm{~mm}$ & 23 & 25 & 0.797 \\
\hline & $\geq 50 \mathrm{~mm}$ & 12 & 10 & \\
\hline \multirow[t]{2}{*}{ Lymphatic invasion } & Negative & 14 & 19 & 0.338 \\
\hline & Positive & 21 & 16 & \\
\hline \multirow{2}{*}{ Venous invasion } & Negative & 17 & 23 & 0.227 \\
\hline & Positive & 18 & 12 & \\
\hline \multirow[t]{2}{*}{ pT } & pT1 & 11 & 22 & $\begin{array}{l}0.016 \\
*\end{array}$ \\
\hline & pT2-3 & 24 & 13 & \\
\hline \multirow[t]{2}{*}{$\mathrm{pN}$} & pNO & 13 & 20 & 0.150 \\
\hline & $\mathrm{pN} 1-3$ & 22 & 15 & \\
\hline \multirow[t]{2}{*}{ pStage } & I-II & 19 & 26 & 0.134 \\
\hline & III-IV & 16 & 9 & \\
\hline \multirow[t]{2}{*}{ Invasive front } & positive & 8 & 17 & $\begin{array}{l}0.045 \\
*\end{array}$ \\
\hline & negative & 27 & 18 & \\
\hline
\end{tabular}

Ut: upper thoracic esophagus; Mt: middle thoracic esophagus; Lt: lower thoracic esophagus; Ae: abdominal esophagus; pT: Pathological T stage; pN: pathological N stage; pStage: pathological stage; SCC: squamous cell carcinoma. ${ }^{*} p<0.05$ : Fisher's exact test.

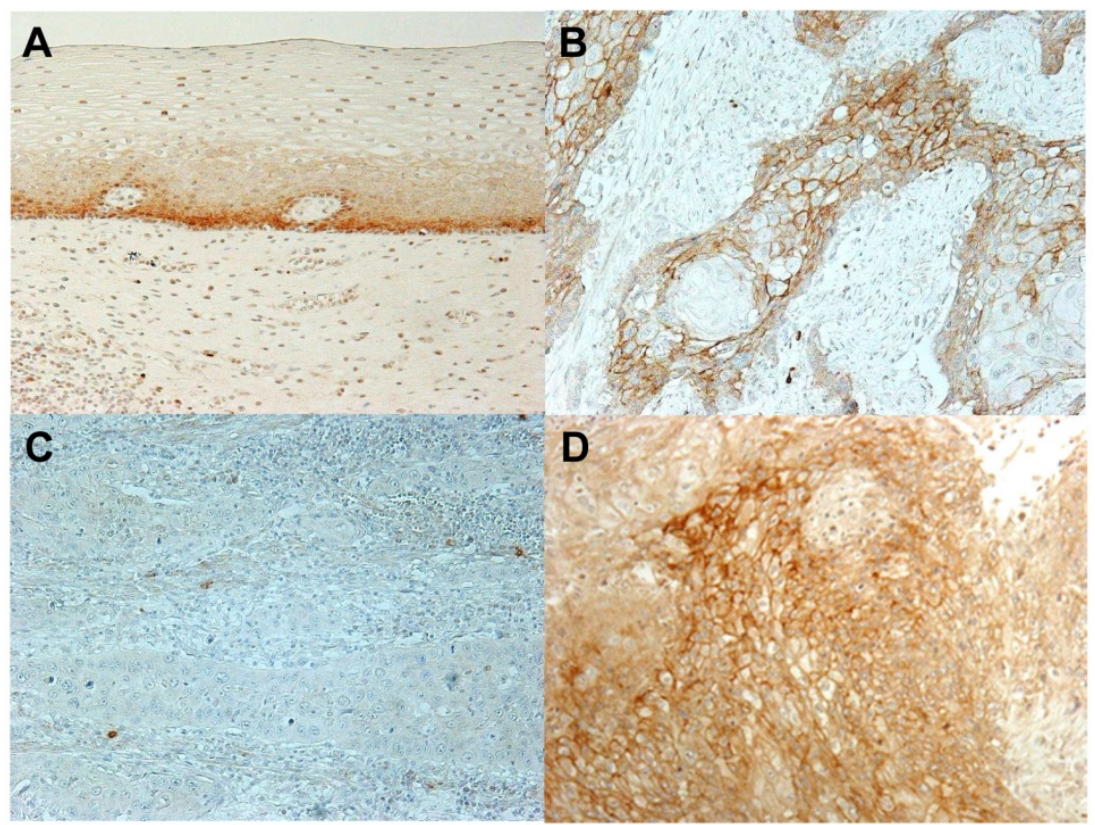

Fig. 1. CA XII protein expression in human esophageal squamous cell carcinoma (ESCC). A: Immunohistochemical staining of non-cancerous esophageal epithelia with the CA XII antibody. Magnification: $\times 200$. B: Immunohistochemical staining of primary human ESCC samples with the CA XII antibody. Magnification: $\times 200$. C: Immunohistochemical staining of primary human ESCC samples with the low grade expression of CA XII. Magnification: $\times 200$. D: Immunohistochemical staining of primary human ESCC samples with the high grade expression of CA XII. Magnification: $\times 200$. 
A
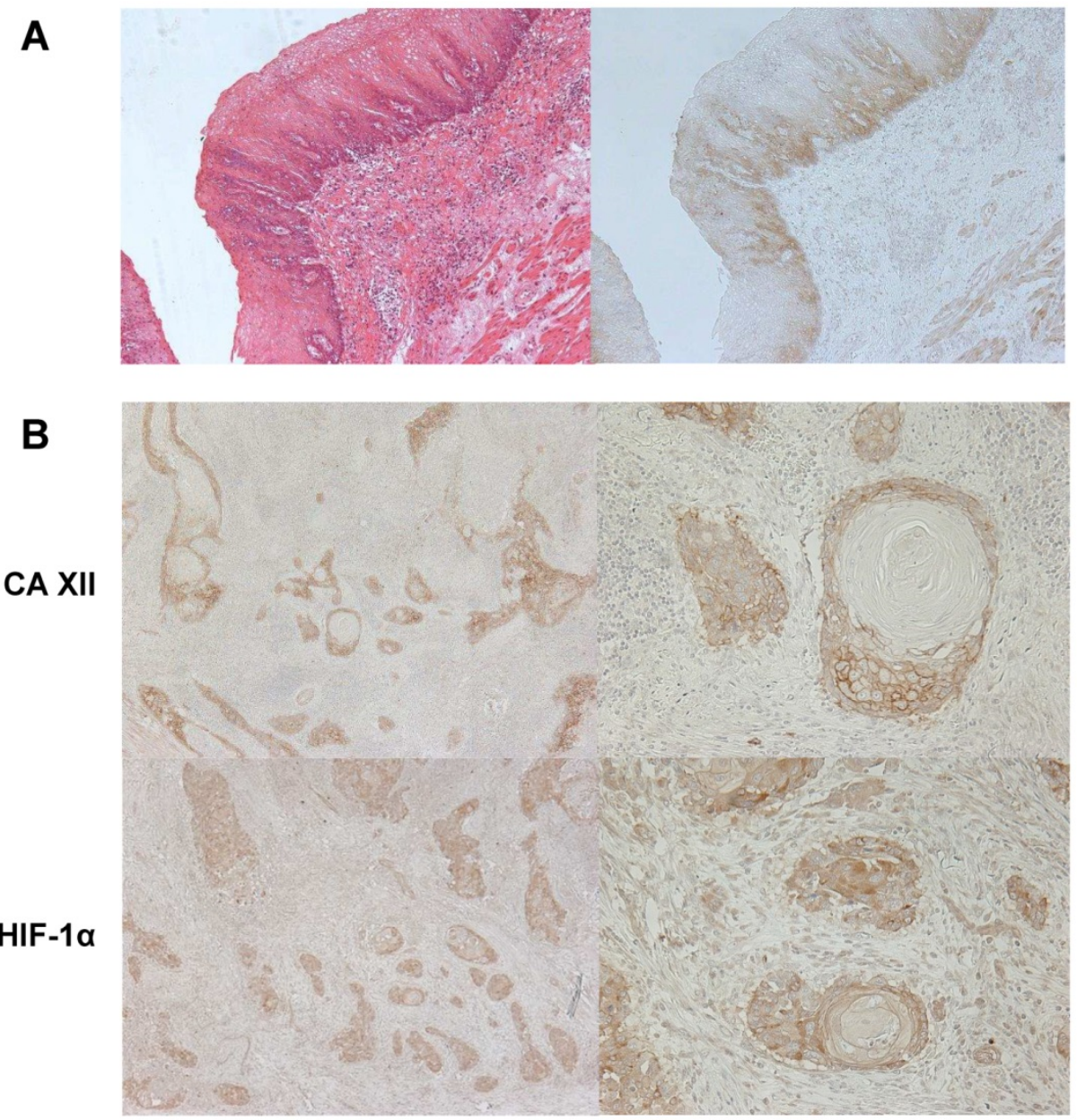

Fig. 2. A: Immunohistochemical staining of human esophageal precancerous tissue with the CA XII antibody. CA XII protein expression was found in esophageal dysplasia. Magnification: $\times 100$. B: The comparison between CA XII and HIF-1 a protein expressions in human ESCC tissues. Immunohistochemical staining patterns of CA XII (high) and HIF-1 $\alpha$ (low) were similar. Magnification: $\times 40$ (left), $\times 200$ (right).

\section{Prognostic impact of CA XII protein expres- sion for patients with ESCC}

We determined the prognostic impact of the expression of CA XII for patients with ESCC. No significant difference was observed in the overall 3-year survival rate between patients with the high grade expression of CA XII and those with the low grade expression of CA XII (Fig. 3A). Similarly, no significant differences were observed in the 3-year survival rate between patients with CA XII expression in the invasive front $(70.8 \%)$ and that of the patients without it $(71.5 \%)(p=0.764)$. We then analyzed the prognostic significance of the expression of CA XII according to the pT category. In patients with pT1 ESCC, no significant difference was observed in the 3-year survival rate between patients with the high grade expression of CA XII and those with the low grade expression of CA XII (Fig. 3B). On the other hand, in patients with pT2-3 ESCC, the 3-year survival rate of patients with the high grade expression of CA XII (29.1\%) was significantly lower than that of patients with the low grade expression of CA XII $(70.3 \%)(p=0.011)$ (Fig. $3 C)$.

We then assessed which of the 10 variables examined (age, gender, location of the primary tumor, histological type, tumor size, lymphatic invasion, venous invasion, $\mathrm{pN}$ category, pStage, and CA XII expression) influenced survival in patients with pT2-3 ESCC following curative resection of esophageal cancer. A univariate analysis of survival following esophagectomy revealed that lymphatic invasion and CA XII expression were significant prognostic factors ( $p=0.041$ and 0.011 , respectively) (Table IV). A multivariate analysis demonstrated that lymphatic invasion, $\mathrm{pN}$ category and CA XII expression were independent prognostic factors $(p=0.003,0.007$ and 0.001 , respectively) (Table V). The expression of CA XII was the strongest prognostic factor among all clinicopathological features. These results suggested that the expression of CA XII may be a valuable prognostic factor for patients with advanced ESCC. 
Table II. Relationships between the expression of CA XII and clinicopathological features of $\mathrm{pT} 1$ esophageal cancer.

\begin{tabular}{|c|c|c|c|c|}
\hline \multicolumn{2}{|l|}{ Variable } & \multicolumn{2}{|l|}{ CA XII } & \multirow[t]{3}{*}{$\begin{array}{l}p \text {-Valu } \\
\mathrm{e}\end{array}$} \\
\hline & & Low & High & \\
\hline & & $\begin{array}{l}\text { Score }<0.5 \\
(\mathrm{n}=11)\end{array}$ & $\begin{array}{l}\text { Score } \geq 0.5 \\
(n=22)\end{array}$ & \\
\hline \multirow[t]{2}{*}{ Age } & $<65$ years & 4 & 11 & 1.000 \\
\hline & $\geq 65$ years & 7 & 11 & \\
\hline \multirow[t]{2}{*}{ Gender } & Male & 10 & 19 & 0.712 \\
\hline & Female & 1 & 3 & \\
\hline \multirow{2}{*}{$\begin{array}{l}\text { Location of the pri- } \\
\text { mary tumor }\end{array}$} & Ut-Mt & 10 & 16 & 1.378 \\
\hline & Lt-Ae & 1 & 6 & \\
\hline \multirow[t]{2}{*}{ Histological type } & $\begin{array}{l}\text { Well/moderately } \\
\text { differentiated SCC }\end{array}$ & 7 & 18 & 0.392 \\
\hline & $\begin{array}{l}\text { Poorly differentiated } \\
\text { SCC }\end{array}$ & 4 & 4 & \\
\hline \multirow[t]{2}{*}{ Tumor size } & $<50 \mathrm{~mm}$ & 10 & 19 & 1.000 \\
\hline & $\geq 50 \mathrm{~mm}$ & 1 & 3 & \\
\hline \multirow[t]{2}{*}{ Lymphatic invasion } & Negative & 6 & 15 & 0.471 \\
\hline & Positive & 5 & 7 & \\
\hline \multirow[t]{2}{*}{ Venous invasion } & Negative & 5 & 18 & $0.049^{*}$ \\
\hline & Positive & 6 & 4 & \\
\hline \multirow[t]{2}{*}{$\mathrm{pN}$} & $\mathrm{pN} 0$ & 7 & 15 & 1.000 \\
\hline & pN1-3 & 4 & 7 & \\
\hline \multirow[t]{2}{*}{ pStage } & I-II & 11 & 19 & 0.534 \\
\hline & III-IV & 0 & 3 & \\
\hline $\begin{array}{l}\text { Ut: upper thoracic eso } \\
\text { esophagus; Ae: abdom } \\
\text { stage; pStage: patholog }\end{array}$ & $\begin{array}{l}\text { agus; Mt: middle thorac } \\
\text { al esophagus; pT: Patho } \\
\text { al stage; SCC: squamou }\end{array}$ & ic esophagus & $\begin{array}{l}\text {; Lt: lower th } \\
\text { ge; pN: patho } \\
\text { ma. }\end{array}$ & $\begin{array}{l}\text { horacic } \\
\text { logical N }\end{array}$ \\
\hline
\end{tabular}

Table III. Relationships between the expression of CA XII and clinicopathological features of pT2-3 esophageal cancer.

\begin{tabular}{|c|c|c|c|c|}
\hline \multicolumn{2}{|l|}{ Variable } & \multicolumn{2}{|l|}{ CA XII } & \multirow[t]{2}{*}{$\begin{array}{l}p \text {-Valu } \\
\mathrm{e}\end{array}$} \\
\hline & & $\begin{array}{l}\text { Low } \\
\text { Score }<0.5 \\
(n=24)\end{array}$ & $\begin{array}{l}\text { High } \\
\text { Score } \geq 0.5 \\
(n=13)\end{array}$ & \\
\hline \multirow[t]{2}{*}{ Age } & $<65$ years & 16 & 9 & 1.000 \\
\hline & $\geq 65$ years & 8 & 4 & \\
\hline \multirow[t]{2}{*}{ Gender } & Male & 20 & 10 & 0.678 \\
\hline & Female & 4 & 3 & \\
\hline \multirow{2}{*}{$\begin{array}{l}\text { Location of the pri- } \\
\text { mary tumor }\end{array}$} & Ut-Mt & 14 & 7 & 1.000 \\
\hline & Lt-Ae & 10 & 6 & \\
\hline \multirow[t]{2}{*}{ Histological type } & $\begin{array}{l}\text { Well/moderately } \\
\text { differentiated SCC }\end{array}$ & 15 & 8 & 1.000 \\
\hline & $\begin{array}{l}\text { Poorly differentiated } \\
\text { SCC }\end{array}$ & 9 & 5 & \\
\hline \multirow[t]{2}{*}{ Tumor size } & $<50 \mathrm{~mm}$ & 13 & 6 & 0.737 \\
\hline & $\geq 50 \mathrm{~mm}$ & 11 & 7 & \\
\hline \multirow[t]{2}{*}{ Lymphatic invasion } & Negative & 8 & 4 & 1.000 \\
\hline & Positive & 16 & 9 & \\
\hline \multirow[t]{2}{*}{ Venous invasion } & Negative & 12 & 5 & 0.731 \\
\hline & Positive & 12 & 8 & \\
\hline \multirow[t]{2}{*}{$\mathrm{pN}$} & $\mathrm{pN} 0$ & 6 & 5 & 0.321 \\
\hline & $\mathrm{pN} 1-3$ & 18 & 8 & \\
\hline \multirow[t]{2}{*}{ pStage } & I-II & 8 & 7 & 0.300 \\
\hline & III-IV & 16 & 6 & \\
\hline
\end{tabular}

Ut: upper thoracic esophagus; Mt: middle thoracic esophagus; Lt: lower thoracic esophagus; Ae: abdominal esophagus; pT: Pathological T stage; $\mathrm{pN}$ : pathological N stage; pStage: pathological stage; SCC: squamous cell carcinoma.

${ }^{*} p<0.05$ : Fisher's exact test.
Table IV. Three-year survival rates of patients with pT2-3 esophageal cancer according to various clinicopathological parameters.

\begin{tabular}{|c|c|c|c|}
\hline Variables & & $\begin{array}{l}3 \text {-year sur- } \\
\text { vival rate }(\%)\end{array}$ & $p$-Value \\
\hline \multirow[t]{2}{*}{ Age } & $<65$ years & 65.6 & 0.658 \\
\hline & $\geq 65$ years & 53.5 & \\
\hline \multirow[t]{2}{*}{ Gender } & Male & 55.4 & 0.628 \\
\hline & Female & 66.7 & \\
\hline \multirow{2}{*}{$\begin{array}{l}\text { Location of the primary } \\
\text { tumor }\end{array}$} & Ut-Mt & 69.1 & 0.193 \\
\hline & Lt-Ae & 42.9 & \\
\hline \multirow[t]{2}{*}{ Histological type } & $\begin{array}{l}\text { Well/moderately differ- } \\
\text { entiated SCC }\end{array}$ & 57.8 & 0.845 \\
\hline & Poorly differentiated SCC & 55.1 & \\
\hline \multirow[t]{2}{*}{ Tumor size } & $<50 \mathrm{~mm}$ & 61.1 & 0.508 \\
\hline & $\geq 50 \mathrm{~mm}$ & 53.9 & \\
\hline \multirow[t]{2}{*}{ Lymphatic invasion } & Negative & 81.8 & $0.041^{*}$ \\
\hline & Positive & 45.5 & \\
\hline \multirow[t]{2}{*}{ Venous invasion } & Negative & 68.4 & 0.251 \\
\hline & Positive & 47.3 & \\
\hline \multirow[t]{2}{*}{$\mathrm{pN}$} & pN0 & 72.7 & 0.184 \\
\hline & pN1-3 & 49.9 & \\
\hline \multirow[t]{2}{*}{ pStage } & I-II & 71.4 & 0.171 \\
\hline & III-IV & 47.2 & \\
\hline \multirow[t]{2}{*}{ CA XII } & Low (Score<0.5) & 70.3 & $0.011^{*}$ \\
\hline & High (Score $\geq 0.5$ ) & 29.1 & \\
\hline
\end{tabular}

Ut: upper thoracic esophagus; Mt: middle thoracic esophagus; Lt: lower thoracic esophagus; Ae: abdominal esophagus; pT: Pathological T stage; $\mathrm{pN}$ : pathological N stage; pStage: pathological stage; SCC: squamous cell carcinoma. ${ }^{*} p<0.05: \log$-rank test.

Table V. Prognostic factors of pT2-3 esophageal cancer according to a multivariate analysis.

\begin{tabular}{|c|c|c|c|c|}
\hline Variables & & Risk ratio & $95 \% \mathrm{CI}$ & $p$-Value \\
\hline \multirow[t]{2}{*}{ Lymphatic invasion } & Negative & Ref & & \\
\hline & Positive & 6.983 & $1.794-47.089$ & $0.003^{*}$ \\
\hline \multirow[t]{2}{*}{$\mathrm{pN}$} & $\mathrm{pN} 0$ & Ref & & \\
\hline & pN1-3 & 5.794 & $1.571-29.697$ & $0.007^{*}$ \\
\hline \multirow[t]{2}{*}{ CA XII } & Low $($ Score $<0.5)$ & Ref & & \\
\hline & High $($ Score $\geq 0.5$ ) & 7.977 & $2.373-30.278$ & $0.001^{*}$ \\
\hline
\end{tabular}

$\mathrm{pN}$ : pathological N stage; Ref: referent.

${ }^{*} p<0.05$ : Cox's proportional hazards model; $95 \%$ CI: 95\% confidence interval.

\section{Discussion}

CA, a class of zinc metalloenzymes that catalyze the reversible hydration of carbon dioxide, participates in various physiological processes by contributing to $\mathrm{pH}$ homeostasis (4). Hypoxia is a common phenomenon in tumors, and is associated with malignant behavior, invasiveness, and a poor prognosis (1). Consequently, CA is thought to regulate the microenvironment and contribute to tumor growth and invasiveness. Fifteen active isoforms of CAs, 12 of which are catalytically active, have been identified in mammals to date (14). Of these, CA IX and XII have been examined in various types of tumors and suggested to play a role in oncogenic processes.

In esophageal cancer, several studies demonstrated that the expression of CA IX correlated with a poor prognosis and malignant phenotype in both 
esophageal adenocarcinoma (15) and ESCC (16). Schoppmann et al. showed that the overexpression of CA IX in esophageal cancer was associated with a poorer prognosis and correlated with the expression of HER-2 $(17,18)$. They also showed that the CA IX-expressing tumor stroma was associated with shorter survival in esophageal cancer (19). However, the roles and clinicopathological meaning of the expression of CA XII in esophageal cancer have not yet been evaluated. In the present study, we investigated the expression of CA XII in ESCC and determined its relationships with clinicopathological features and prognosis. To the best of our knowledge, this is the first study to examine the expression of CA XII in human esophageal cancer tissue.

A

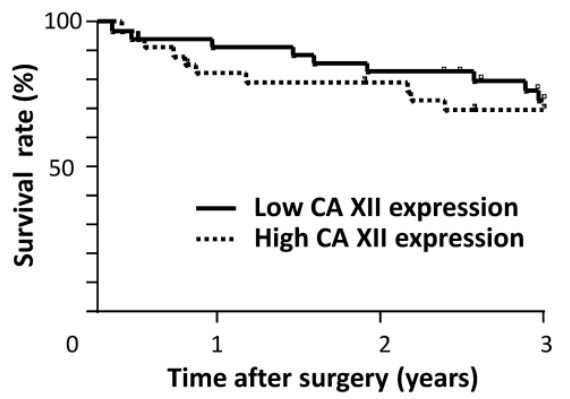

B

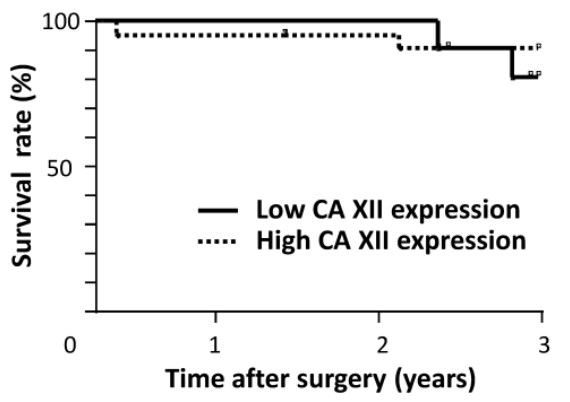

C

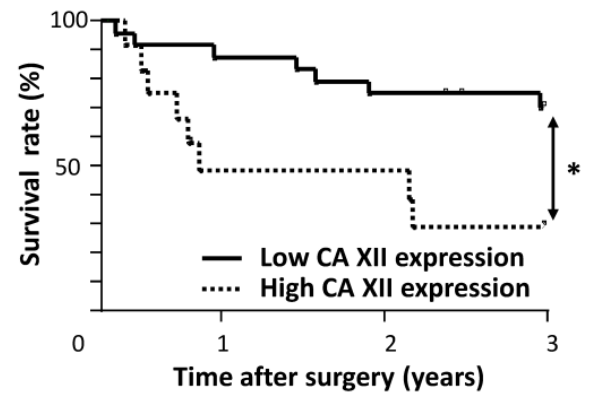

Fig. 3. Survival curve of patients after curative resection for esophageal squamous cell carcinoma (ESCC) according to the expression of CA XII. A: All patients were classified into two groups: the low grade expression of CA XII $(n=35)$ and high grade expression of CA XII $(n=35)$. B: Patients with PTI ESCC were classified into two groups: the low grade expression of CA XII $(n=11)$ and high grade expression of CA XII $(n=22)$. C: Patients with PT2-3 ESCC were classified into two groups: the low grade expression of CA XII $(n=24)$ and high grade expression of CA XII $(n=13)$. ${ }^{*} p<0.05$ : log-rank test.

CA XII is a transmembrane and extracellular enzyme that is involved in regulating the acidity of the microenvironment and tumorigenesis $(2,4)$. The overexpression of CAXII was initially detected in re- nal cell carcinoma, and subsequent studies confirmed its expression in various human neoplasms, such as astrocytoma, glioblastoma, breast, ovarian, cervical, lung, and head and neck cancers (4-11). Although several studies investigated the relationship between CA XII expression and tumor malignance, the prognostic significance of CA XII in neoplasms remains controversial. Previous studies showed that CA XII could be considered as a positive prognostic predictor in lung, breast, and cervical cancers $(5,7,8)$, whereas others showed that CA XII was a negative prognostic predictor in astrocytoma, glioblastoma, and oral squamous cell carcinoma (9-11). In the present study, we initially found that the expression of CA XII was related to the $\mathrm{pT}$ category and that the expression of CA XII was found in precancerous tissue, which suggested that it was expressed from the early stage of carcinogenesis. Ilie et al. reported that the mRNA and protein levels of CA XII were rapidly down-regulated by a shift to normoxia in non-small cell lung cancer cells, and suggested that cancer cells may require hypoxia-inducible CAXII expression at the early stages of oncogenesis (20). They also indicated that the dynamic CAIX and CAXII response to hypoxia-re-oxygenation promoted aggressive tumor growth. On the other hand, our results showed the expression of CA XII was one of the most important poor prognostic factors in pT2-3 ESCC. Several studies demonstrated that the gene expression of HIF-1 increased at the same time as the overexpression of CA XII, suggesting that CA XII predicts a poor prognosis in circumstances in which the expression of HIF-1 is also elevated $(21,22)$. Although this mechanism needs to be elucidated in more detail in further studies, our results suggest the important and specific roles of CAXII in advanced ESCC.

Regarding results of CA XII immunohistochemistry, some parabasal cells in normal esophageal mucosa seem to show rather nuclear immuno-reactivity as opposed to cancer cells where staining of cell membrane has been identified. Recent reports indicate that CA IX interacts with proteins involved in nuclear/cytoplasmic transport, gene transcription, and protein stability, suggesting the existence of nuclear CA IX protein subpopulations with a potential intracellular function, distinct from the crucial CA IX role at the cell surface $(23,24)$. Although roles of CA $\mathrm{XII}$ in nuclear have not been fully investigated, our results suggest that there are some differences of CA XII function between normal epithelial cells and cancer cells.

Recent studies reported that ion channels/transporters play important roles in fundamental cellular functions, and a cellular physiological approach is currently regarded as a promising target for 
specific cancer treatments (25). We previously investigated the roles of ion transporters (26-30), water channels (31), and regulator of intracellular $\mathrm{pH}$ (32) in esophageal and/or gastric cancer. $\mathrm{pH}$ regulators, such as anion exchangers, sodium-hydrogen exchangers, vacuolar $\mathrm{H}^{+}$-ATPases, and CAs, have the potential to be key therapeutic targets and the silencing of their expression could provide a new therapeutic strategy in future (25). CA IX and XII are predominantly found in tumor cells and lack (or are present in very limited amount) in normal tissues, and therefore, the potential use of CA inhibitors as antitumor agents opens thus a new important research direction (33). In renal cell carcinoma (RCC), the chimeric monoclonal antibody WX-G250 has been developed for therapeutic purposes. It recognises the CA-IXMN/G250 antigen expressed in $95 \%$ of clear cell RCC $(34,35)$. The reactivity of WX-G250 with normal tissues is restricted to the gastric epithelium and the biliary ducts in the liver, astrocytes in the brain and to the spinal cord, and WX-G250 therapy in patients with metastatic RCC has already shown that its toxicity is mild $(34,35)$. Whereas the CA IX-specific inhibition is under clinical development for therapeutic and diagnostic application, much less is known about CA XII. However, several specific inhibitors of CA XII have already been developed and studied $(33,36,37)$, and, therefore, our results may provide an insight into novel hypoxic targeting therapy for ESCC.

In conclusion, the expression of CAXII in ESCC was revealed for the first time in the present study. We found that its expression was a valuable prognostic factor for patients with advanced ESCC. A deeper understanding of the role of CAXII may lead to its use as a crucial biomarker of tumor progression and/or a new therapeutic target for ESCC.

\section{Acknowledgments}

This work was supported by Grants-in-Aid for Young Scientists (B) (24791440) and a Grant-in-Aid for Scientific Research (C) (26461988) from the Japan Society for the Promotion of Science.

\section{Conflict of interest}

The authors declare that they have no conflict of interest.

\section{References}

1. Pouyssegur J, Dayan F and Mazure NM: Hypoxia signalling in cancer and approaches to enforce tumour regression. Nature. 2006;441:437-443.

2. Potter $\mathrm{CP}$ and Harris AL: Diagnostic, prognostic and therapeutic implications of carbonic anhydrases in cancer. Br J Cancer. 2003;89:2-7.

3. Poulsen SA: Carbonic anhydrase inhibition as a cancer therapy: a review of patent literature, 2007-2009. Expert Opin Ther Pat. 2010;20:795-806.

4. Parkkila S, Parkkila AK, Saarnio J, Kivela J, Karttunen TJ, Kaunisto K, Waheed A, Sly WS, Tureci O, Virtanen I and Rajaniemi H: Expression of the membrane-associated carbonic anhydrase isozyme XII in the human kidney and renal tumors. J Histochem Cytochem. 2000; 48:1601-1608.
5. Watson PH, Chia SK, Wykoff CC, Han C, Leek RD, Sly WS, Gatter KC, Ratcliffe P and Harris AL: Carbonic anhydrase XII is a marker of good prognosis in invasive breast carcinoma. Br J Cancer. 2003;88:1065-1070.

6. Hynninen P, Vaskivuo L, Saarnio J, Haapasalo H, Kivela J, Pastorekova S, Pastorek J, Waheed A, Sly WS, Puistola U and Parkkila S: Expression of transmembrane carbonic anhydrases IX and XII in ovarian tumours. Histopathology. 2006;49:594-602.

7. Yoo CW, Nam BH, Kim JY, Shin HJ, Lim H, Lee S, Lee SK, Lim MC and Song YJ: Carbonic anhydrase XII expression is associated with histologic grade of cervical cancer and superior radiotherapy outcome. Radiat Oncol. 2010;5:101.

8. Ilie MI, Hofman V, Ortholan C, Ammadi RE, Bonnetaud C, Havet K, Venissac N, Mouroux J, Mazure NM, Pouyssegur J and Hofman P: Overexpression of carbonic anhydrase XII in tissues from resectable non-small cell lung cancers is a biomarker of good prognosis. Int J Cancer. 2011;128:1614-1623.

9. Haapasalo J, Hilvo M, Nordfors K, Haapasalo H, Parkkila S, Hyrskyluoto A, Rantala I, Waheed A, Sly WS, Pastorekova S, Pastorek J and Parkkila AK: Identification of an alternatively spliced isoform of carbonic anhydrase XII in diffusely infiltrating astrocytic gliomas. Neuro Oncol. 2008;10:131-138.

10. Proescholdt MA, Mayer C, Kubitza M, Schubert T, Liao SY, Stanbridge EJ, Ivanov S, Oldfield EH, Brawanski A and Merrill MJ: Expression of hypoxia-inducible carbonic anhydrases in brain tumors. Neuro Oncol. 2005;7:465-475.

11. Chien MH, Ying TH, Hsieh YH, Lin CH, Shih $\mathrm{CH}$, Wei LH and Yang SF: Tumor-associated carbonic anhydrase XII is linked to the growth of primary oral squamous cell carcinoma and its poor prognosis. Oral Oncol. 2012;48:417-423

12. Sobin L, Gospodarowicz M and Wittekind C (eds.): TNM Classification of Malignant Tumors. Seventh edition. Hoboken, NJ: John Wiley \& Sons, Inc., 2009.

13. Remmele $\mathrm{W}$ and Stegner HE: Recommendation for uniform definition of an immunoreactive score (IRS) for immunohistochemical estrogen receptor detection (ER-ICA) in breast cancer tissue. Pathology. 1987;8:138-140.

14. Hsieh MJ, Chen KS, Chiou HL and Hsieh YS: Carbonic anhydrase XII promotes invasion and migration ability of MDA-MB-231 breast cancer cells through the p38 MAPK signaling pathway. Eur J Cell Biol. 2010;89:598-606.

15. Driessen A, Landuyt W, Pastorekova S, Moons J, Goethals L, Haustermans K, Nafteux P, Penninckx F, Geboes K, Lerut T and Ectors N: Expression of carbonic anhydrase IX (CA IX), a hypoxia-related protein, rather than vascular-endothelial growth factor (VEGF), a pro-angiogenic factor, correlates with an extremely poor prognosis in esophageal and gastric adenocarcinomas. Ann Surg. 2006;243:334-340.

16. Tanaka N, Kato H, Inose T, Kimura H, Faried A, Sohda M, Nakajima M, Fukai Y, Miyazaki T, Masuda N, Fukuchi M and Kuwano H: Expression of carbonic anhydrase 9, a potential intrinsic marker of hypoxia, is associated with poor prognosis in oesophageal squamous cell carcinoma. $\mathrm{Br} \mathrm{J}$ Cancer. 2008;99:1468-1475

17. Schoppmann SF, Jesch B, Friedrich J, Jomrich G, Maroske F and Birner P: Phosphorylation of signal transducer and activator of transcription 3 (STAT3) correlates with Her-2 status, carbonic anhydrase 9 expression and prognosis in esophageal cancer. Clin Exp Metastasis. 2012;29:615-624.

18. Birner P, Jesch B, Friedrich J, Riegler M, Zacherl J, Hejna M, Wrba F, Schultheis A and Schoppmann SF: Carbonic anhydrase IX overexpression is associated with diminished prognosis in esophageal cancer and correlates with Her-2 expression. Ann Surg Oncol. 2011;18:3330-3337.

19. Jomrich $G$, Jesch B, Birner $P$, Schwameis $K$, Paireder $M$, Asari $R$ and Schoppmann SF: Stromal expression of carbonic anhydrase IX in esophageal cancer. Clin Transl Oncol. 2014;16: 966-972.

20. Ilie M, Hofman V, Zangari J, Chiche J, Mouroux J, Mazure NM, Pouyssegur J, Brest $\mathrm{P}$ and Hofman P: Response of CAIX and CAXII to in vitro re-oxygenation and clinical significance of the combined expression in NSCLC patients. Lung Cancer. 2013;82:16-23.

21. Harima $Y$, Togashi A, Horikoshi $K$, Imamura M, Sougawa M, Sawada $S$, Tsunoda T, Nakamura Y and Katagiri T: Prediction of outcome of advanced cervical cancer to thermoradiotherapy according to expression profiles of 35 genes selected by cDNA microarray analysis. Int J Radiat Oncol Biol Phys. 2004;60:237-248

22. Chao A, Wang TH and Lai CH: Overview of microarray analysis of gene expression and its applications to cervical cancer investigation. Taiwan J Obstet Gynecol. 2007:46:363-373.

23. Buanne P, Renzone G, Monteleone F, Vitale M, Monti SM, Sandomenico A, Garbi C, Montanaro D, Accardo M, Troncone G, Zatovicova M, Csaderova L, Supuran CT, Pastorekova S, Scaloni A, De Simone G and Zambrano N: Characterization of carbonic anhydrase IX interactome reveals proteins assisting its nuclear localization in hypoxic cells. J Proteome Res. 2013;12:282-292.

24. Sasso E, Vitale M, Monteleone F, Boffo FL, Santoriello M, Sarnataro D, Garbi C, Sabatella M, Crifo B, Paolella LA, Minopoli G, Winum JY and Zambrano N: Binding of carbonic anhydrase IX to $45 \mathrm{~S}$ rDNA genes is prevented by exportin-1 in hypoxic cells. Biomed Res Int. 2015; 2015:674920.

25. Shiozaki A, Ichikawa D, Otsuji E and Marunaka Y: Cellular physiological approach for treatment of gastric cancer. World J Gastroenterol. 2014;20:11560-11566.

26. Shiozaki A, Takemoto $K$, Ichikawa $D$, Fujiwara $H$, Konishi $H$, Kosuga $T$, Komatsu S, Okamoto K, Kishimoto M, Marunaka Y and Otsuji E: The K-Cl cotransporter $\mathrm{KCC} 3$ as an independent prognostic factor in human esophageal squamous cell carcinoma. Biomed Res Int. 2014;936401. 
27. Shiozaki A, Nako Y, Ichikawa D, Konishi H, Komatsu S, Kubota T, Fujiwara H, Okamoto K, Kishimoto M, Marunaka $\mathrm{Y}$ and Otsuji E: Role of the $\mathrm{Na}+/ \mathrm{K}+/ 2 \mathrm{Cl}-$ cotransporter $\mathrm{NKCC} 1$ in cell cycle progression in human esophageal squamous cell carcinoma. World J Gastroenterol. 2014;20:6844-6859

28. Iitaka D, Shiozaki A, Ichikawa D, Kosuga T, Komatsu S, Okamoto K, Fujiwara $\mathrm{H}$, Ishii $\mathrm{H}$, Nakahari $\mathrm{T}$, Marunaka $\mathrm{Y}$ and Otsuji E: Blockade of chloride ion transport enhances the cytocidal effect of hypotonic solution in gastric cancer cells. J Surg Res. 2012;176:524-534.

29. Shiozaki A, Otsuji E and Marunaka Y. Intracellular chloride regulates the G1/S cell cycle progression in gastric cancer cells. World J Gastrointest Oncol. 2011;3:119-122.

30. Miyazaki H, Shiozaki A, Niisato N, Ohsawa R, Itoi H, Ueda $Y$, Otsuji E, Yamagishi H, Iwasaki Y, Nakano T, Nakahari T and Marunaka Y: Chloride ions control the G1/S cell-cycle checkpoint by regulating the expression of p21 through a p53-independent pathway in human gastric cancer cells. Biochem Biophys Res Commun. 2008;366:506-512.

31. Shimizu H, Shiozaki A, Ichikawa D, Fujiwara H, Konishi H, Ishii H, Komatsu S, Kubota T, Okamoto K, Kishimoto M and Otsuji E: The expression and role of Aquaporin 5 in esophageal squamous cell carcinoma. J Gastroenterol. 2014;49:655-666

32. Hosogi S, Miyazaki H, Nakajima K, Ashihara E, Niisato N, Kusuzaki K and Marunaka Y: An inhibitor of $\mathrm{Na}+\mathrm{H}+$ exchanger (NHE), ethyl-isopropyl amiloride (EIPA), diminishes proliferation of MKN28 human gastric cancer cells by decreasing the cytosolic $\mathrm{Cl}$ - concentration via DIDS-sensitive pathways. Cell Physiol Biochem. 2012;30:1241-1253.

33. Brzozowski Z, Slawinski J, Innocenti A and Supuran CT: Carbonic anhydrase inhibitors. Regioselective synthesis of novel 1-substituted 1, 4-dihydro-4-oxo-3-pyridinesulfonamides and their inhibition of the human cytosolic isozymes I and II and transmembrane cancer-associated isozymes IX and XII. Eur J Med Chem.2010;45:3656-3661.

34. Bleumer I, Knuth A, Oosterwijk E, Hofmann R, Varga Z, Lamers C, Kruit W, Melchior S, Mala C, Ullrich S, De Mulder P, Mulders PF and Beck J: A phase II trial of chimeric monoclonal antibody G250 for advanced renal cell carcinoma patients. Br J Cancer. 2004:90:985-990.

35. Siebels M, Rohrmann K, Oberneder R, Stahler M, Haseke N, Beck J, Hofmann R, Kindler M, Kloepfer P and Stief C: A clinical phase I/II trial with the monoclonal antibody cG250 (RENCAREX®) and interferon-alpha-2a in metastatic renal cell carcinoma patients. World J Urol. 2011;29:121-126.

36. Battke C, Kremmer E, Mysliwietz J, Gondi G, Dumitru C, Brandau S, Lang S, Vullo D, Supuran C and Zeidler R: Generation and characterization of the first inhibitory antibody targeting tumour-associated carbonic anhydrase XII. Cancer Immunol Immunother. 2011;60:649-658.

37. Brzozowski Z, Slawinski J, Saczewski F, Innocenti A and Supuran CT: Carbonic anhydrase inhibitors: synthesis and inhibition of the human cytosolic isozymes I and II and transmembrane isozymes IX, XII (cancer-associated) and XIV with 4-substituted 3-pyridinesulfonamides. Eur J Med Chem. 2010;45:2396-2404. 